\title{
Leuit and prohibition forest: Indigenous knowledge of an Urug community resilience
}

\author{
Bahagia Bahagia ${ }^{1 *}$, Fachrudin Majeri Mangunjaya ${ }^{2}$, Rimun Wibowo ${ }^{3}$, Zulkifli Rangkuti \\ ${ }^{3}$, Muhammad Azhar Alwahid ${ }^{4}$ \\ ${ }^{1}$ Universitas Ibn Khaldun Bogor. \\ Jl. K.H. Sholeh Iskandar Raya Km. 2, Kedung Badak, Bogor, Jawa Barat 16161, Indonesia. \\ ${ }^{2}$ Pascasarjana, Universitas Nasional Jakarta. \\ Jl. Sawo Manila, Jati Padang, Jakarta Selatan, DKI Jakarta 12520, Indonesia. \\ ${ }^{3}$ Pascasarjana, Sekolah Tinggi Manajemen IMMI. \\ J1. Tj. Barat Raya No. 11, Pejaten Timur, Jakarta Selatan, DKI Jakarta 12530, Indonesia. \\ ${ }^{4}$ LPM Equator Bogor \\ J1. Letjen Ibrahim Adjie No. 197, Bogor Barat, Bogor, Jawa Barat 16117, Indonesia. \\ bahagiagia59@yahoo.co.id \\ * Corresponding Author
}

ARTICLE INFO
Article History
Received:
7 July 2020;
Revised:
29 July 2020;
Accepted:
18 August 2020
Keywords
Climate;
Indigenous-knowledge ;
Leuit;
Prohibition of forest
and resilience;

\section{ARTICLE INFO}

Article History

7 July 2020;

Revised:

29 July 2020

Accepted:

Keywords

Climate;

Indigenous-knowledge ;

Prohibition of forest

\begin{abstract}
This research aimed to investigate the function of leuit and prohibition forest based on indigenous knowledge of Urug people for combating climate change toward community resilience. The research method used an ethnographic qualitative approach. This method was related to local cultural, ritual, and traditional communities, the data collected through in-depth interviews, observation, and documentation. The selection of sample as informant exert purposive sampling technique. The result is probed meticulously through triangulation technique and triangulation sources. The result shows that traditional storage (leuit) has a role in confronting climate change and disaster and life perturbance for achieving community resilience. Another finding is Urug people create a prohibition forest. The impact is the wood can rescue from damage. The community can fight climate change, get adequate water, and environment preservation.
\end{abstract}

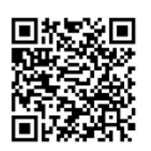

This is an open access article under the CC-BY-SA license.

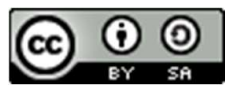

\section{INTRODUCTION}

Climate and environmental dynamics can be a significant obstacle for human life, including increasing drought frequency, irregular rainfall patterns, heat waves, and other extreme events throughout the world (Arora, 2019). Farming has contributed to climate change for producing agricultural emissions. While emerging pollution can be categorized as a fundamental factor to impact global warming. In addition, large farms often grow the same plants every year, use large amounts of pesticides and fertilizers, soil damage, water pollution, loss of nutrients in the land, reduce biodiversity, and contribute to climate change (Pareek, Dhankher, \& Foye, 2020). As a result, it increases the likelihood of crop failures in the short-run, and production declines in the long run (Tun Oo, Van Huylenbroeck, \& Speelman, 2020). Another impact can create numerous ecology disasters, including cyclones, floods, and bushfires (Schiermeier, 2018).

Meanwhile, indigenous people have combated climate and environmental change for extended periods as well as local knowledge can be adapted to the environment dynamically. The experience 
comprises the rules or policy locally, life guidance, and life solutions. The culture is not documented, but it is transferred orally through folklore, proverb, and learning by action. The member of the community directly involves without getting training but act immediately in the field. In this, their ancestor young teaches generation by practice the knowledge in the area. Indigenous knowledge has a connection to social-ecological knowledge because indigenous knowledge through cultural and social policy preserves the ecological environment. Indigenous people have experienced climate and environmental change as well as the way to fight climate change (Ford, King, Galappaththi, Pearce, McDowell, \& Harper, 2020).

Even social and ecological systems can define as a connection between the human system and nature for bolster resilience. At the same time, resilience may mention humans' capacity to respond by adapting, self-organizing, and learning (Folke, 2016). The resilience of the social-ecological system is also influenced by social factors such as the ability of people to anticipate changes and plans for the future (adaptive and capacity), which in turn are shaped by human institutions, institutional rules, and the level of exposure to and the impact of global changes on human life (RuizMallén \& Corbera, 2013). Thus, ecological and social resilience are dynamically interrelated by developing natural resource management forms and subsequent responses from biophysical systems. For instance, they diversify plants with native varieties that are resistant to climate change, creating protected areas to increase ecosystem resilience and providing important ecosystem services such as erosion control, beach stabilization, and water retention (Lo, 2016).

In addition, indigenous peoples and their knowledge have been engaged in environmental monitoring through various participatory arrangements (Thompson, Lantz, \& Ban, 2020). Observing natural phenomena and monitoring can create community resilience because local people know about the environment's dynamic. Local people will adapt and act to face climate and environmental change. To fight climate change, people can diversify income sources (Seddon, Chausson, Berry, Girardin, Smith, \& Turner, 2020). Farmers decide whether soil fertile and unfertile based on soil layer color. Dark color soil is a clue of high fertility soil (Buthelezi, Hughes \& Modi, 2010). To determine season and whether indigenous knowledge observes distribution, migration, and population of deer.

When the snow rate is low, deer will far too human because deer migrate to hill and mountain. Conversely, when heavy snow, deer close to humans, and people easily capture deer (de Echeverria \& Thornton, 2019). Besides that, in Msinga, village communities observe nature clues like lack of number leaves in June and July have meant that the sweltering period occurs. People also envisage wild dogs when they come to people's housing. The animals experience food shortages in the forest (Rukema \& Umubyeyi, 2019). If frogs (Rana sp.) croak from water bodies in the evening for an extended time, this is said to signify that rain is approaching. Abnormal spider spinning, such as producing shorter and thicker webs, can predicts rain (Inaotombi \& Mahanta, 2018). The knowledge about the season period can attaint resilience because people have predicted the next perturbances in life.

In numerous traditional people in Indonesia, there are actions to create community resilience to the environment, climate, and food security. In Baduy people, Baduy sells some of their agricultural products to the market and store some of them as their personal use. They keep paddies for themselves and do not sell them. Usually, after harvest, the paddies are dried and immediately placed in the leuit. The implementation can create food security, food independence, food availability, and access to food communities to cultivate plant variation in the soil (Yulia, Prakarsa, \& Fauzi, 2018). The other way to fight climate change, people in rural areas still wield Pranata Mongo as a guide to determine the seasons and climate. It looks like the traditional calendar to show the cultivation period can be released or must be postponed (Mukti \& Noor, 2018). In the Ciptagelar community, people have a strategy to overcome climate dynamics such as crop rotation. People cultivate paddy once in a year, plant cucumbers, chilies, beans, and other seasonal crops. If water is sufficient, the community will make rice fields into fish ponds. This indicates that the community has known a good crop rotation system to improve soil physical, biological and chemical properties (Hapsari, Hapsari, Karyani, \& Fatimah, 2018).

Additionally, traditional people create sacred zonation, such as the forest. Each person will not be allowed to visit in the vicinity of the area (Janaki, Rishi, \& Sharma, 2020). The result, taboo or 
prohibition contributes to natural resource management and biodiversity conservation. Typically, taboo has a connection to cultural warning or ban against an action, such that violating a taboo is an act of serious aberrance that can result in feelings of guilt or shame and direct or indirect social sanction (Williams \& Shipley, 2017). Consequently, community resilience can be attained because people can combat climate because taboo can conserve the environment and create community resilience from water scarcity. After all, forests have a pivotal role in protecting water underground. In addition, the living condition of the livelihood of indigenous people can undermine community resilience, including social capital, natural capital, and finance capital (Melore \& Nel, 2020).

This research will not test the previous finding. Still, the research is to investigate the authenticity of the Urug community in Bogor West java for confronting climate and environmental change through leuit or traditional paddy storage to face climate and environmental obstacles as well as achieve community resilience. The other will trace the connection of prohibition of forest link to preserving the environment, combat climate, and conserve the environment.

\section{METHOD}

The research about the leuit and prohibition forest for fighting Climate Change for reacting community resilience base on Indigenous Knowledge of Urug Community toward community resilience exerts ethnography with the qualitative approach method. This research is conducted in Urug village, Sukajaya District, Bogor Regency West Java Indonesia. Ethnography is the study of social and local culture, especially in indigenous communities, as well as the local ritual of costumary community. The fundamental principle is the researcher must settle and observe profoundly about local cultural and social phenomena. Observation is central to the ethnography method, where the researcher spends an extended time in a social group to collect data (Morgan-Trimmer \& Wood, 2016). Methods are distinct from methodology and refer to the particular tools used to conduct research, such as interviews or focus groups. Ethnography uses standard qualitative tools, such as interviews, but is unique in adding observations (both participant and non-participant), field notes, textual analysis, and collecting what are called artifacts (Webster \& Rice, 2019).

Ethnography has been considered the hallmark of anthropology since all aspects of fieldwork and participant observation are based on ethnography's fundamental principles, and it is a logic of investigation (Rodrigues-Júnior, 2012). Besides, the qualitative method is used to understand people's beliefs, experiences, attitudes, behavior, and interactions (Pathak, Jena, \& Kalra, 2013). There are numerous qualitative research techniques, including small-group discussions, semistructured interviews, and in-depth interviews. Small-group discussions to investigate related to beliefs, attitudes, and concepts of normative behavior. At the same time, semi-structured interviews to seek views on a focused topic. In addition, in-depth interviews to understand a condition, experience, or event from a personal perspective (Hammarberg, Kirkman, \& Lacey, 2016).

For data analysis, field-notes and audio-recordings are transcribed into protocols and transcripts and coded using qualitative data management software. Criteria such as checklists, reflexivity, sampling strategies, piloting, co-coding, member-checking, and stakeholder involvement can be used to enhance the quality of the research (Busetto, Wick, \& Gumbinger, 2020). In addition, ethnography can be mentioned as fieldwork research, where the researcher visits fields and objects to find complete information. A purposive sampling technique is applied to collect samples. This technique collects the best data from archives relating to the social and cultural aspects of the original Urug community. Key people fit this research like abah Ukat as chief in Urug community.

It was possible to explain in depth about the purpose of this study. As the chief, abah Ukat has the most in-depth knowledge compared to others in Urug. Then, abah Ukat decides another person who knows food and agriculture. Data gathered through in-depth interviews with abah Ukat. Data were collected includes traditional storage, namely leuit, to save paddy for fighting climate change toward community resilience. Another gathered data was about the prohibition forest's connection to overcome climate change and environmental issues for attaining community resilience. The other data were secondary. Data were be collected from numerous sources of data, including journals and books, which are linked to indigenous knowledge. Besides that, observation is another

Volume 7, No. 2, September 2020 
Bahagia Bahagia, Fachrudin Majeri Mangunjaya, Rimun Wibowo, Zulkifli Rangkuti, Muhammad Azhar Alwahid

way for data collection. Observation can mention as collecting data from observing directly, such as viewing to object and location or real fact of application of indigenous knowledge.

All data were examined by triangulation data to get valid data. One approach to promote social change, mitigate bias, and enhance reaching data saturation is triangulation (multiple data) (Fusch, Fusch, \& Ness, 2018). Triangulation data are combined among data sources, including primary sources of data from keys persons of Urug people and data from observation, interviews, and documentation. For example, an issue that was identified during an interview or focus group could also be examined during observations of practice in the naturalistic work setting. Similarly, issues witnessed during observations or recorded in digital diaries could be explored during discussions (Johnson, O'Hara, Hirst, Weyman, Turner, Mason, ... Siriwardena, 2017). The research and observations are made in the real world (Sawatsky, Ratelle, \& Beckman, 2019). The combination sources of data, namely interview, observation, and documentation, can be reliable for this research.

\section{FINDINGS AND DISCCUSIONS}

\section{Leuit or Traditional Paddy Storage for Fighting Global Warming}

Global warming has affected life widely. There are many clues about it, including altering climate patterns, erratic rainy season, rising earth temperature to create warmer earth, and environmental disaster. Urug community has overcome this disturbance by storing paddy in leuit. Leuit is traditional paddy storage. Pratiwi \& Kusdiwanggo (2018) reveal that leuit can be mentioned as the paddy house. The building of leuit is separated from the house, but the location relatively close. Leuit is made of wood and bamboo. The roof is made of palm leaves, the wall of leuit used wooden bamboo, and the building is a stage. The wooden disc is used to avoid mouse or other rodent animals to enter the leuit (Yulia, Prakarsa, \& Fauzi, 2018). Leuit can indicate the social status of people. If someone has some leuit, it indicates that the person has abandoned the paddy yield. In this building, paddy with a panicle will be distributed to leuit after paddy dries naturally.

Leuit can preserve the quality of paddy until 25 years. Connected to leuit is building drying, better circulation, better humidity, and free from insects because pests cannot enter this building. Besides that, people have vanished the liquid of paddy steadily. The people let paddy in lantayan until the grain of paddy dries out. This is a traditional tool for drying paddy. This process can ensure the quality of paddy. The Urug people have a fundamental principle that people must store paddy and not trade paddy or rice to market. For them, paddy will not be permitted for trading by the leader of Urug people. Generally, each people have traditional paddy storage, namely leuit. People will comply leuit after the harvesting period. The Sunda tribe encourages food security by storing the food in leuit (Khomsan, Riyadi, \& Marliyati, 2013).

People will not sell the paddy from leuit until the new paddy yields are collected because the paddy yield can jump or decrease in a year. Meanwhile, eco-disaster can hit a person at any time. The people use this appliance for saving paddy, but people never keep rice in leuit. If someone needs to fulfill the need, the person will take some paddy. There are rules where the people cannot open leuit the same day when entering paddy. For Instance, when people save paddy on Saturday, the people must gather paddy in leuit on Friday. There is a difference between the new leuit and the old leuit. As society has invented new leuit, the people must demand permission to the chief of Urug community. Although leuit is owned privately, each person must follow the rules where the people cannot save their paddy yield without admission from the chief.

For keeping paddy, the leader of Urug determines Saturday dan Thursday are appropriate date and day of Urug leader. To gather paddy from leuit, the people cannot gather paddy twice on the same day but must be on the other day, such as Sunday. After all, paddy is saved in leuit, leader of Urug conduct nganyaran (first time for cooking) after collecting paddy yield. The Urug community has the freedom to produce rice, but they will not cook rice for the first time before the Urug leader has not created a meal. As a member of people who has envisaged that the leader has cooked, they will follow later. Typically for abah Ukat family, his wife asks the leader of Urug for questioning when the first time to produce rice from paddy in leuit?. All of the wives will be mutely for producing paddy to rice (not talking to the leader). After completing, the next step is asking the 
leader, namely abah Ukat, when is the best time for cooking. After the leader decides, the wife will be silent until rice is cooked.

This behavior just for new rice or the first time after the harvest period. The next time, the wife will not ask for permission. These are the same rules for Urug society; for the first time of yield, the people will curtail to produce the rice. The amount of rice production is only for fulfilling the basic need for this day. Meaning that the people will obtain freedom to produce rice after this community holds Serantaun. Serantaun is a traditional Urug people ceremony after the harvest period, and everyone must conduct this ritual. The other is Urug people prefer to keep paddy rather than rice. People understand that distributing rice in leuit is easy to decay. It causes the rice can't support people's food because rice quality can be worse than paddy. Another reason is the Urug believes that human life must face many difficulties, including people who can experience mild to severe illness. When people suffer from diseases, people cannot work anymore and must rest in bed to cure.

As paddy has been stockpiled in leuit, people can tackle these issues, and people will not experience starvation. Besides, Urug people convince that each person can be vulnerable to disasters like eco-catastrophe, including sliding and flooding. People will not get difficulty with hunger if people have ample stock food in leuit. Even, Urug people anticipate the production rate of paddy, farmers can produce a good harvest, but the person also can obtain less production. To combat these perturbances, leuit is the solution. Another is leuit has a connection to cultural and social, there is leuit communal. This leuit will be played as food sources for people who lives in a hard situation. Paddy from this leuit can be lent to people they need most (Nopianti, 2016).

Another function of leuit is to keep some seeds for cultivating the next period. Urug people will not select seed in the field because the quality of paddy grains can be categorized as all edible seeds. For seed, the old paddy must not be mixed with a new harvest except the old layer's location in the button about two up to four layers. Paddy seeds will be collected from the first layer of the new layer. Conversely, if old stock is used to seed, the paddy will not grow in the seedling area. Action to store paddy can be categorized as adaptive resilience. Adaptive resilience (gradual adjustment and flexibility) requires long-term preventive strategies or actions (before shocks) (Endris, Kibwika, Hassan, \& Obaa, 2017). Nevertheless, people will be allowed to sell rice when the new rice yield is sufficient to meet the family's needs. Others have identified many obstacles, including eco-catastrophe, pest, bird, and ecological disasters. It can even plunder someone from external threats such as rat attacks (Hosen, Nakamura, \& Hamzah, 2020). Because the stock was previously provided, they were able to overcome this situation. They hate hearing about the rice trade because they think that trade can deplete stock ready to survive. Tradition in this cultural behavior is handed over from those who access it.

Their forefather teaches them that rice trading is baned from thousand of years ago. Another finding is in the Baduy tribe, selling paddy grain is baned (Iskandar and Iskandar,2017). Urug people have applied this action to ensure that everyone is free from starvation. Another reason considers that paddy is life; if people sell paddy, they have vanished life (Damayanti, Hafiz, Mi'raj, Dwiyanto, \& Aun, 2020). Besides that, traditional people trust about Dewi Sri (goodness of Sri). People's firm belief that people do not salvage paddy in leuit will be given catastrophe. When people keep paddy in leuit because they respectfully about what they have trusted that people can obtain debacle If people breach this local knowledge (Miharja, 2018). Traditional people also believe that if people have a house, the paddy must have a place (Nopianti, 2016). However, Urug people will permit societies to sell paddy if there is proof that paddy is successful. It can be better if the harvest is stored in storage instead of old stock. For them, rice is a fundamental necessity. Without rice, they can not rekindle, but the other food, such as vegetables just complementary. Abah Ukat has taught basic community principles like they never eat what they obtain today, but they must strive to seek food outside of paddy in the traditional store. They have gathered food like rice again before expending pill stock in leuit.

Abah Ukad said that we must eat what we have not acquired today. This fundamental view raises people's motivation to strive or work harder, although they have attained their basic need from paddy yield. Meaning that, although they have bestowed abandoned paddy grain, they purchase rice from outside to avoid taking paddy from traditional storage. The paddy in store will be consumed

Volume 7, No. 2, September 2020 
when unpredictable evident occurs. They think that although paddy has been farmed properly to schedule and base on emerging insect attacks, it can decline production. He also said rice is more imperative than other food such as fish, salt, vegetables, and fruits. They do not need to purchase vegetables because vegetables like spun can find rampant everywhere in the forbidden forest. Another is that Vegetable fern may engage as an essential vegetable in Urug. In contrast, fish can be obtained in various rivers, including Cidurian river, Ciapus, and Cibitung river. All the rivers pass Urug village.

Also, they look for fish in the rice paddy field like an eel. Besides that, they allocate the funding for buying garlic, onion, potato, and other food sources. If we connected to global issues like climate pandemic, which is world issues, storing fundamental necessities like paddy grain is the pivotal mitigation. The action like this has a tight connection for creating a resilience community when a person confronts an eco-catastrophe, climate, and severe ailment. Climate disturbance will not hinder the Urug people because they have food in the traditional store. Despite climate combat, the environment and people have created to increase their resilience based on traditional storage for organic food. Even they can combat climate obstacles, human disease, and misery because lack of food pilled for years. The other way is that the person will not gather what they have like paddy in storage but struggle to find other subsistence sources to fulfill they need.

The strategy creates healthier people to confront difficulties next time for the primary food sources that have not decreased because they look at other sources to give family food. Meaning that they stock, especially paddy, is still full in storage, but they obtain new food stock. The old stock is ready for a person without reducing the stock, one resilient indication when an individual can reach security food (Raheem, 2018). Indigenous people like Urug have provided food through saving paddy grain rather than rice in traditional storage. It aims to secure food like rice for the family in the long term and the community. At the same time, Urug people are easy to access food because leuit is constructed nearby houses. When they need rice, they will take some to fulfill necessities. Another connection is when the paddy saves with skin, it can create an extended period for grain to decay. This way, storage can extend the ages of paddy grain until composting.

\section{Larangan Forest Create Community Resilience}

Forests have a pivotal role in ensuring water for people, abolishing emissions from the atmosphere, producing oxygen, and conserving numerous species plants. Urug people protect forests by creating forest prohibition or sacred mountains. The policy at the local level comes from their forefather. The recent generation continues the local rules. In Urug perspective, the forest is mandatory from their ancestor and gods. As compulsory, the zonation must assert to function and avoid damaging. People also perceive that each person has entitlement for utilizing land. Another rule is each person will not permit to collect wood resources in forest prohibition. Even people will not be allowed to gather leaf and wood composting in this location. In a sacred place, Urug people let both big and small trees and bushes grow density. At the same time, the leader of Urug people visits this location for meditation. Prohibition policies have been implemented without any person dare to breach the rules from their forefathers. People will not dare to alter the practices of their forefathers.

As a generation, they just adherer to local rules. However, no punishment will endure to the perpetrator who dares to offenses rules, but everyone is convinced about kualat. It is related to a person who profoundly convinces that the person will obtain the impact like unsuccessfully in life, experience catastrophe, and confront a difficult situation. He said that each member believes that the outbreak can fight people who dare to offend the local policy they have handed over from their forefathers. Every person who has a trust to the impact of behavior, they will save from catastrophe. Spiritual beliefs like the people trust there is a harmful impact on life when the person dares to breach this policy can continue the conservation of the natural resource in the territory (Chunhabunyatip, Sasaki, Grünbühel, Kuwornu, \& Tsusaka, 2018). It can bolster by people's perception that a forest is a forbidden place where there is a guardian to save the forest, home for fearsome guardians where it can peril for people (Uyeda, Iskandar, Purbatrapsila, Pamungkas, Wirsing, \& Kyes, 2014). This leads 
to a positive attitude equated with obedience because local people were found not to harvest firewood or hunt in the sacred forest because of respect and fear (Sinthumule \& Mashau, 2020).

It is unscientific, but it can keep people from acting abrasive against nature. The impact is the mountain peak is safe from damage, and global warming can overcome because Larangan Forest is valuable to the environment. In the Sunda language, the forest is similar to leuweng. In this location, there are numerous trees, small trees, big trees, bushes, grow density, and fertility. Even various plant vegetables like fen and medicine plants grow well in the prohibited area. This action can save plants from damage because no person will gather resources in a prohibited area, including wood, animals, water, and wild vegetable. Event people will not admit collecting composted leaves or woods in the vicinity of the city. It let all kinds of trees, bushes, and wild animals inhabitants sacred zones like Larangan Forest. Prohibition action or taboos and beliefs also regulate people to visit nature (Alexander, Agyekumhene, \& Allman, 2017). It is scientific that Urug people's behavior can integrate into science.

When people allow trees to grow in location, it can be useful for the environment because the soil in the prohibition location's vicinity will become fertile naturally without allocating artificial fertilizer. The diversity of trees can result in a variety of litter of tress. It gives different nutrients to the soil (Jahed \& Hosseini, 2014). Even the diversity of trees and richness of trees affect the soil nutrient (Nadeau \& Sullivan, 2015). There will be many kinds of worm and fungus gather advantage from wood and leaf composting. There is an ecology cycle in this location where plants as sources for animal feeding and part of the plant, including branch, leaves, fruit, and flower, which fall to land, have an imperative role in alleviating soil degradation. In other findings, prohibited location implies medical interest. It can also assist the community's effort to protect and conserve water, a necessary resource (Aluko, 2019).

The impact of people restriction on the sacred area can reduce biodiversity loss (Shemdoe, 2016 in Roué, 2016). It can limit people to exploit wild animals in nature for food (Angsongna, Armah, Boamah, Hambati, Luginaah, Chuenpagdee, \& Campbell, 2016). Directly, both water in the river and spring water will not cease because forests and water have a secure connection. When trees cover the land, the water supply will be available (Ilstedt et al. 2016 in Ellison et al. 2017). Meanwhile, the lack of forest inland impact to less water to get into the soil. Even the forest has numerous merits, including stabilizing runoff, reducing erosion, and improving biodiversity and water quality (Eriksson, Samuelson, Jägrud, Mattsson, Celander, Malmer, ... Tengberg, 2018). As a result, forest forbidden can create community capacity and meet basic needs such as water. When the drying period occurs, people have enough stock to fight hotter summer and react to water resistance. Besides, water for agricultural irrigation will be sufficient because water from rivers such as the Cidurian river and the Ciapus river can use for agricultural production.

Rivers, such as Cidurian, become primary sources of water for irrigation because Urug community still relies on the water river naturally to irrigate their rice paddy field instead of modern irrigation, Urug people block this river for irrigation. Around Urug people, there are two rivers, such as the Cidurian river and the Ciapus river. Ciapus river is close to Larangan forest. It gives people the advantage for the Urug people to use spring water as a basic need. In some findings, there are stringent relations between wood and supply of water. The other function of Larangan forest is insuring sufficient oxygen for people. Each plant, both small and big, have a role in producing oxygen. Forbidden forest areas can reduce emissions because vegetation finds rampant very well around the location. Each tree and part of curls such as leaf, root, and stump have an imperative role in reducing emission. Forests mitigate climate change effects such as warming and acidification (Mátyás \& Sun, 2014).

Even the diversity of plants in one location, such as the variety of high-sized trees, the thick leaf of tress, and the combination of plants, including trees, herbaceous plant, and other plants, have a significant role in the decline of emission (Aji, D.A., 2018). In general, each tree can decline the emission rate. The photosynthesis process in trees absorb Carbon dioxide and water, and then trees alter it into Glucose and Oxygen with sunlight (Chamid at all 2018). The plant's basic principle to decline emission is by directly sequestering carbon through photosynthesis (direct carbon reduction) and avoiding carbon emissions by building energy savings or indirect carbon reduction (Hyun-Kil 
Jo at al. , 2019). The connection between social-ecological resilience is indigenous of Urug people, like creating prohibited areas, can fight many environment dynamics.

The community can adapt the change because of the function of sacred forest play for an extended period of water preservation. When dry season occurs next period, the stock of water in Larangan location can assert that people need water. Then, stabilization of temperature because Larangan forest has a pivotal function to decrease emission, which is a primary factor in global warming. As a result, the people in Urug can adapt to the environment and climate dynamics. People in Urug have mitigated climate variation directly since the sacred area create. Conversely, indigenous knowledge that a cultural system where taboo principle overlooks forest conservation may lead to numerous issues, including increasing deforestation, destruction of water bodies, prolonged drought, and loss of soil fertility (Asante, Ababio, \& Boadu, 2017).

\section{CONCLUSION}

Traditional knowledge has adapted to the environment and climate dynamics through observation and learning by acting locally. The experience has transferred by practicing activity and undocumented because indigenous people transfer the knowledge orally. It leads to indigenous knowledge that can combat global warming and climate by storing paddy in leuit and ban the people from ravaging prohibition of location like forest zone. In the leuit or traditional storage of paddy, Urug people save paddy for confronting climate and environment as well as life obstacles to ensure that the community will not lack food. As a result, as Urug people have never experienced starvation because they abandon of paddy for consumption. There are rules locally where the people will not trade paddy because they believe that paddy may not be sold for commercial purposes. People must ensure to fulfill fundamental necessities for confronting climate, disaster, and disease in their perception. Secondly, the prohibition forest is mandatory from the forefather as protection from damaged. People as custodians of the environment because people convince that each person who dares to breach the policy like collecting wood in the prohibition forest will experience catastrophe. It can result in protecting water, animal habitats and reducing emission rates because trees play a role in declining emissions. As a result, the people of Urug can attaint community resilience because they can combat climate change and environmental issues.

\section{REFERENCES}

Alexander, L., Agyekumhene, A., \& Allman, P. (2017). The role of taboos in the protection and recovery of sea turtles. Frontier Marine Science, 4, 237. doi:https://doi.org/10.3389/fmars.2017.00237

Aluko, Y. A. (2018). Women's use of indigenous knowledge for environmental security and sustainable development in Southwest Nigeria. International Indigenous Policy Journal, 9(3), 1-25. doi:https://doi.org/10.18584/iipj.2018.9.3.2

Angsongna, A., Ato Armah, F., Boamah, S., Hambati, H., Luginaah, I., Chuenpagdee, R., \& Campbell, G. (2016). A systematic review of resource habitat taboos and human health outcomes in the context of global environmental change. Global Bioethics, 27(2-4), 91-111. doi:https://doi.org/10.1080/11287462.2016.1212608

Arora, N. K. (2019). Impact of climate change on agriculture production and its sustainable solutions. Environmental Sustainability, 2(1), 95-96. doi:https://doi.org/10.1007/s42398-019-00078$\underline{\mathrm{w}}$

Asante, E. A., Ababio, S., \& Boadu, K. B. (2017). The use of indigenous cultural practices by the Ashantis for the conservation of forests in Ghana. SAGE Open, 7(1), 1-7. doi:https://doi.org/10.1177/2158244016687611

Busetto, L., Wick, W., \& Gumbinger, C. (2020). How to use and assess qualitative research methods. Neurological Research and Practice, 2(14), 1-10. doi:https://doi.org/10.1186/s42466-020$\underline{00059-\mathrm{Z}}$ 
138 - Harmoni Sosial: Jurnal Pendidikan IPS

Chunhabunyatip, P., Sasaki, N., Grünbühel, C., Kuwornu, J. K., \& Tsusaka, T. W. (2018). Influence of indigenous spiritual beliefs on natural resource management and ecological conservation in Thailand. Sustainability, 10(8), 2842. doi:https://doi.org/10.3390/su10082842

Damayanti, A., Hafiz, A. Z., Mi'raj, A. A., Dwiyanto, M. R., \& Auni, R. (2020). The local wisdom and land use of paddy field in Sukarame Village, Cisolok Sub-district, Sukabumi Regency. Jurnal Pendidikan Geografi: Kajian, Teori, dan Praktek dalam Bidang Pendidikan dan Ilmu Geografi, 25(1), 17-24.

de Echeverria, V. R. W., \& Thornton, T. F. (2019). Using traditional ecological knowledge to understand and adapt to climate and biodiversity change on the Pacific coast of North America. Ambio, 48(12), 1447-1469. doi:https://doi.org/10.1007/s13280-019-01218-6

Endris, G. S., Kibwika, P., Hassan, J. Y., \& Obaa, B. B. (2017). Harnessing social capital for resilience to livelihood shocks: Ethnographic evidence of indigenous mutual support practices among rural households in Eastern Ethiopia. International Journal of Population Research, 2017. doi:https://doi.org/10.1155/2017/4513607

Eriksson, M., Samuelson, L., Jägrud, L., Mattsson, E., Celander, T., Malmer, A., ... \& Tengberg, A. (2018). Water, Forests, people: The Swedish experience in building resilient landscapes. Environmental Management, 62(1), 45-57. doi:https://doi.org/10.1007/s00267-018-1066-x

Folke, C. (2016). Resilience (republished). Ecology and Society, 21(4).

Ford, J. D., King, N., Galappaththi, E. K., Pearce, T., McDowell, G., \& Harper, S. L. (2020). The resilience of Indigenous peoples to environmental change. One Earth, 2(6), 532-543.

Fusch, P., Fusch, G. E., \& Ness, L. R. (2018). Denzin's paradigm shift: Revisiting triangulation in qualitative research. Journal of Social Change, 10(1), 2.

Hammarberg, K., Kirkman, M., \& de Lacey, S. (2016). Qualitative research methods: When to use them and how to judge them. Human Reproduction, 31(3), 498-501. doi:https://doi.org/10.1093/humrep/dev334

Hapsari, H., Hapsari, D., Karyani, T., \& Fatimah, S. (2019). Adaptation of indigenous community agricultural systems on climate change (case study of Kasepuhan Ciptagelar, Sukabumi Regency, West Java). IOP Conference Series: Earth and Environmental Science, 306(1), 012031.

Hosen, N., Nakamura, H., \& Hamzah, A. (2020). Adaptation to climate change: Does traditional ecological knowledge hold the key?. Sustainability, 12(2), 676. doi:https://doi.org/10.3390/su12020676

Inaotombi, S., \& Mahanta, P. C. (2018). Pathways of socio-ecological resilience to climate change for fisheries through indigenous knowledge. Human and Ecological Risk Assessment: An International Journal, 25(8), 1-15. doi:https://doi.org/10.1080/10807039.2018.1482197

Jahed, R. R., \& Hosseini, S. M. (2014). The effect of natural and planted forest stands on soil fertility in the Hyrcanian region, Iran. Biodiversitas Journal of Biological Diversity, 15(2), 206-214. doi:https://doi.org/10.13057/biodiv/d150213

Janaki, M., Pandit, R., \& Sharma, R. K. (2020). The role of traditional belief systems in conserving biological diversity in the Eastern Himalaya Eco-region of India. Human Dimensions of Wildlife, 25(5), 1-18. doi:https://doi.org/10.1080/10871209.2020.1781982

Johnson, M., O’Hara, R., Hirst, E., Weyman, A., Turner, J., Mason, S., ... \& Siriwardena, A. N. (2017). Multiple triangulation and collaborative research using qualitative methods to explore decision making in pre-hospital emergency care. BMC Medical Research Methodology, 17(1), 1-11. doi:https://doi.org/10.1186/s12874-017-0290-z 
Khomsan, A., Riyadi, H., \& Marliyati, S. A. (2013). Ketahanan pangan dan gizi serta mekanisme bertahan pada masyarakat tradisional Suku Ciptagelar di Jawa Barat. Jurnal Ilmu Pertanian Indonesia, 18(3), 186-193.

Lo, V. (2016). Synthesis report on experiences with ecosystem-based approaches to climate change adaptation and disaster risk reduction. Montreal: Secretariat of the Convention on Biological Diversity.

Melore, T. W., \& Nel, V. (2020). Resilience of informal settlements to climate change in the mountainous areas of Konso, Ethiopia and QwaQwa, South Africa. Jàmbá: Journal of Disaster Risk Studies, 12(1), 1-9. doi:http://dx.doi.org/10.4102/jamba.v12i1.778

Miharja, D. (2018). Keberagamaan masyarakat Sunda. Bandung: LP2M UIN Sunan Gunung Djati Bandung.

Morgan-Trimmer, S., \& Wood, F. (2016). Ethnographic methods for process evaluations of complex health behaviour interventions. Trials, 17(1), 232. doi:https://doi.org/10.1186/s13063-016$\underline{1340-2}$

Mukti, A. S., \& Noor, T. I. (2018). Kearifan lokal dalam sistem agribisnis padi sawah, Desa Sukanagara, Kecamatan Lakbok, Kabupaten Ciamis, Provinsi Jawa Barat. Jurnal Ilmiah $\begin{array}{llll}\text { Mahasiswa AGROINFO GALUH, } & \text { 8(3), }\end{array}$ doi:http://dx.doi.org/10.25157/jimag.v4i3.1657

Nadeau, M. B., \& Sullivan, T. P. (2015). Relationships between plant biodiversity and soil fertility in a mature tropical forest, Costa Rica. International Journal of Forestry Research, 2015, 113. doi:https://doi.org/10.1155/2015/732946

Nopianti, R. (2016). Leuit si Jimat: Wujud solidaritas sosial masyarakat di Kasepuhan Sinarresmi. Patanjala, 8(2), 219-234. doi:https://doi.org/10.30959/patanjala.v8i2.74

Pareek, A., Dhankher, O. P., \& Foyer, C. H. (2020). Mitigating the impact of climate change on plant productivity and ecosystem sustainability. Journal of Experimental Botany, 72(2), 451-456. doi:https://doi.org/10.1093/jxb/erz518

Pathak, V., Jena, B., \& Kalra, S. (2013). Qualitative research. Perspectives in clinical research, 4(3). doi:https://doi.org/10.4103/2229-3485.115389

Raheem, D. (2018). Food and nutrition security as a measure of resilience in the Barents Region. Urban Science, 2(3), 72. doi:https://doi.org/10.3390/urbansci2030072

Rodrigues-Júnior, A.S. (2012). Ethnography: method only or logic of inquiry in field research in Brazil?. Trabalhos em Linguística Aplicada, 51(1), 35-49. doi:https://doi.org/10.1590/S0103-18132012000100003

Ruiz-Mallén, I., \& Corbera, E. (2013). Community-based conservation and traditional ecological knowledge: Implications for social-ecological resilience. Ecology and Society, 18(4), 12.

Rukema, J. R., \& Umubyeyi, B. S. (2019). Indigenous knowledge approach in maintaining a livelihood in the face of disastrous climate change: Case of drought in Msinga villages, KwaZulu-Natal. Jàmbá: Journal of Disaster Risk Studies, 11(1), 1-10. doi:http://dx.doi.org/10.4102/jamba.v11i1.758

Sawatsky, A. P., Ratelle, J. T., \& Beckman, T. J. (2019). Qualitative research methods in medical education. Anesthesiology: The Journal of the American Society of Anesthesiologists, 131(1), 14-22. doi:https://doi.org/10.1097/ALN.0000000000002728

Schiermeier, Q. (2018). Droughts, heatwaves and floods: How to tell when climate change is to blame. Nature, 560(7716), 20-22. doi:https://doi.org/10.1038/d41586-018-05849-9

Seddon, N., Chausson, A., Berry, P., Girardin, C. A., Smith, A., \& Turner, B. (2020). Understanding the value and limits of nature-based solutions to climate change and other global challenges. 
140 - Harmoni Sosial: Jurnal Pendidikan IPS

Philosophical Transactions of the Royal Society B, 375(1794). doi:https://doi.org/10.1098/rstb.2019.0120

Sinthumule, N. I., \& Mashau, M. L. (2020). Traditional ecological knowledge and practices for forest conservation in Thathe Vondo in Limpopo Province, South Africa. Global Ecology and Conservation, 22, 1-11. doi:https://doi.org/10.1016/j.gecco.2020.e00910

Thompson, K. L., Lantz, T., \& Ban, N. (2020). A review of Indigenous knowledge and participation in environmental monitoring. Ecology and Society, 25(2). doi:https://doi.org/10.5751/ES$\underline{11503-250210}$

Tun Oo, A., Van Huylenbroeck, G., \& Speelman, S. (2020). Measuring the economic impact of climate change on crop production in the dry zone of Myanmar: A ricardian approach. Climate, 8(1), 9. doi:https://doi.org/10.3390/cli8010009

Uyeda, L. T., Iskandar, E., Purbatrapsila, A., Pamungkas, J., Wirsing, A., \& Kyes, R. C. (2016). The role of traditional beliefs in conservation of herpetofauna in Banten, Indonesia. Oryx, 50(2), 296-301. doi:https://doi.org/10.1017/S0030605314000623

Webster, F., \& Rice, K. (2019). Conducting ethnography in primary care. Family Practice, 36(4), 523-525. doi:https://doi.org/10.1093/fampra/cmz007

Williams, D. H., \& Shipley, G. P. (2018). Cultural taboos as a factor in the participation rate of Native Americans in STEM. International Journal of STEM Education, 5(1), 17. doi:https://doi.org/10.1186/s40594-018-0114-7

Yulia, R., Prakarsa, A., \& Fauzi, A. (2018). Leuit and customary violation in Baduy (Case study of leuit fire in Cisaban Baduy village). Jurnal Dinamika Hukum, 18(1), 47-53. doi:http://dx.doi.org/10.20884/1.jdh.2018.18.1.1606 